\title{
Existing status and constraints of tie and dye craftsmen of Mewar Region of Rajasthan
}

\author{
Shikha Dashora, Meenu Srivastava and Pragaya Dashora
}

Received: 01.09.2020; Revised: 10.10.2020; Accepted: 24.10.2020

See end of the paper for authors' affiliations

\section{Shikha Dashora}

Department of Textiles and

Apparel Designing, College of

Community and Applied Science,

Maharana Pratap University of

Agricultural andTechnology,

Udaipur (Rajasthan) India

Email : shikhadashora27@gmail.

com
ABSTRACT : Indian Tie and Dye is the oldest craft tradition initiated before five hundred years ago and is even practiced today. This craft is flourishing with Gujarat and Rajasthan as chief production centers. The paper focuses present status and constraints faced by tie and dye craftsmen of Mewar region of Rajasthan. Study sample consist of craftsmen, who prepare the traditional headgear through tie and dye. Forty five (45) craftsmen from Udaipur, Chittorgarh and Bhilwara city of Mewar Region of Rajasthan were selected by snow-ball sampling method. Structured interview schedule was developed and administered for collecting the data. Study result indicates present scenario of tie and dye craft, production, pattern, design, motifs, finishing, material needed and constraints faced by craftsmen by calculating frequency and percentage.

KEY WORDS: Status, Constraints, Craftsmen, Mewar, Tie and Dye

- HOW TO CITE THIS PAPER : Dashora, Shikha, Srivastava, Meenu and Dashora, Pragaya (2020). Existing status and constraints of tie and dye craftsmen of Mewar Region of Rajasthan. Asian J. Home Sci., 15 (2) : 206-212, DOI: 10.15740/HAS/AJHS/15.2/206-212. Copyright@ 2020: Hind Agri-Horticultural Society. 